\title{
Personification as a method for displaying an individual author style (on the material of A. Fet's poetry)
}

\author{
K.P. Shkil \\ Potebnia Institute of Linguistics, National Academy of Sciences of Ukraine, Kyiv, Ukraine \\ Corresponding author. E-mail: shkil_ekaterina@ukr.net
}

Paper received 13.08.20; Accepted for publication 04.09.20.

https://doi.org/10.31174/SEND-Ph2020-234VIII69-12

\begin{abstract}
The article is devoted to the study of the concepts of "trope" and "stylistic figure". The article aims to consider the personification as a way of displaying the individual-author style of A. Fet. Designs using personification, forming the individual-author style of A. Fet, are analyzed and typologized. A poetic text is a unified and indivisible poetic symbol, in terms of information and communication, all levels of which are interdependent. The functions of poetic language are notable for semantic diversity. The individual style of the poet is a communicative-cognitive space of a linguistic personality, which is formed in the artistic discourse. The language of the individual style has a linguotypological essence since it manifests with the individual styles of other personalities the artistic discourse of the era.
\end{abstract}

Keywords: trope, stylistic figure, personification, individual author style.

Introduction. When characterizing the independence of the poetic style of a particular author or when emphasizing the peculiarities of the poetic language, the originality of functioning and language expression in the poetic text of tropes "as units of poetic language that arrange its tropical level" plays a crucial role [12, p. 10]. Beyond that, it is important to identify the most peculiar features of stylistic means as a result of their application in a poetic text. Personification, as a special linguostylistic and compositional technique, is of the utmost interest for the poetic language in the system of a particular individual style.

The following people contributed a lot to the study of tropes as figures used to make the language even more picturesque and emphasize the artistic expressiveness of speech, A. Gornfeld, V. Grigoriev, Yu. Lotman, A. Nikolaev, M. Panov, M. Petrovsky, V. Toporov, A. Fedorov, E. Cherkasov. Such researches as Yu. Belchikov, Ya. Gin, I. Ionova, A. Kvyatkovsky, A. Narushevich, I. Rodnyanskaya and others also studied personification.

The topicality of the research lies in the pursuance of an enhanced understanding of individual specific means of expressing the linguistic personality of a poet.

The purpose of the article is to analyze the stylistic role of personification for artistic and expressive functions. To achieve the above purpose it is necessary to resolve the following tasks: considering the function of personalization; identifying the features of application of personifications as means of poetic language, considering the subject and object of personification; studying the language techniques of personification; selecting and classifying the constructions that include personification in the poetic language of A. Fet.

The object of the research is personification as a linguostylistic technique characterizing poetic language in the system of a particular individual style.

The scope of the research is the personifications presented in the poems of A. Fet.

1. The concept of "trope". Linguistic units play a stylistic role in a poetic text. Tropes and figures of speech are considered the means for improving the expressiveness. According to A. Kvyatkovsky, tropes are poetic constructions revealing themselves in the metaphorical and figurative use of words, phrases, and expressions [4, p. 312] V. Yartseva states that tropes are "such constructions (images) that are based on the use of a word (or a combination of words) in a figurative sense and are applied to make the speech even more picturesque and expressive" [25, p. 520] A trope is a stylistic technique that means the use of words (phrases and sentences) naming one object (thing, phenome- non, property) to characterize another object associated with one or another meaning relation. It can be a relation of similarity, and then we refer to a metaphor, comparison, personification. Or it can be a relation of contrast, and in such a case we refer to oxymorone or antiphrasis. It can be a relation of adjacency, for instance, metonymy. Or it can be a relation of quantity rather than of quality, expressed using synecdoche, hyperbole, or meiosis. Tropes are used to transfer evaluative meaning or emotional and expressive creation of figurativeness. So, they are mainly used in artistic speech. Tropes are characterized by "an unstructured linguistic form" [16, p. 559]. They may be present in one word, a group of words, a sentence, a group of sentences [16, p. 559]. Different types of tropes as well as different ways of combining them are activated in poetry. It is possible to combine different tropes in one linguistic unit. These combinations create a metaphorical epithet, a metaphorical comparison, a hyperbolic comparison, or a hyperbolic epithet. "It becomes possible to talk about the reversibility of tropes connecting the entire space of the structure of tropes" [18, p. 521]. According to a systematic approach to the study of the expressive language means and their terminological meaning, it would make sense to consider the concepts of a stylistic figure and a trope as varieties in relation to the generic concept of a stylistic technique [16, p. 452]. An outstanding feature of the stylistic figure as a kind of stylistic technique is its "relatively formalized nature (the presence of a syntactic scheme, model)" [16, p. 452]. Stylistic figures are poetic syntax phenomena because they are the key carriers of the stylistic component that makes the author's speech more stylistically colorful and contributes to the understanding of the mechanism of aesthetic presentation of certain syntactic structures in individual language expression. It is possible to define tropes as semantically two-dimensional designation used as means to enrich the artistic speech; thus, a trope-speech should be understood as "enriched, movable speech" [13, p. 158-159]. Stylistic figures are irregular syntactic constructions, which ignore linguistic norms, used to make a speech more vivid. Stylistic figures that are widely used in poetry are designed not only to individualize the author's speech but also to make it more emotional, to emphasize artistic originality [7, p. 656]. Based on the above definition, belonging to the category of tropes should be determined according to three criteria: 1) significance (a trope is a nominative unit); 2) twodimensionality (semantic criterion); 3) decorativeness (a functional criterion supposing the limited scope of use of tropes in artistic speech; this is an origin of such expressions as "artistic tropes", "poetic tropes", as well as the definition 
of a trope as "a word-image under the constitutive guidance of an internal artistic, poetic form" [24, p. 147].

When looking for the most adequate definition of the concept of "trope", researchers emphasize a number of peculiar features. V. Odintsov pays attention to "the two-part nature (two-dimensionality) of a trope, which, on the one hand, supposes the transfer of the meaning of words, the use of the word metaphorically and figuratively (hidden, internal, allegoric side of a trope); on the other hand, when realizing a figurative sense, the strict (literal) sense of the word is preserved" [11, p. 246]. Tropes accelerate the imagery and expressiveness of a piece of work, the author's text becomes more colorful and individualized.

2. Personification as a stylistic technique. The literary language of A. Fet's poetry is vibrant since the author uses various artistic techniques and linguistic means (tropes and figures) providing his texts with a special figurativeness. Personification is the most frequently-used trope in Fet's poetry.

A list of lexical definitions of personification is multivarious.

So, the encyclopedia "Russian Language" defines personification as "one of the types of allegory: a stylistic technique stating that an inanimate object, an abstract concept, a living being, which does not have consciousness, is attributed to the traits or actions of a human being" [2, p. 176]. The "Poetic Dictionary" by A. Kvyatkovsky defines personification as a stylistic figure stating that when describing animals, natural events or inanimate objects, they are attributed to human feelings, thoughts and speech (anthropomorphism) [4, p. 183]. The Dictionary of Linguistic Terminology, understand personification as "a trope attributing signs and traits of living beings to inanimate objects (personification)" [15, p. 175]. The same dictionary defines personification as "a trope attributing signs and traits of a human being to inanimate objects and abstract concepts" [15, p. 207]. The encyclopedic literary dictionary defines personification as "a specific type of metaphor", with a further gradation of personification "depending on its functions in artistic speech": a) personification as a stylistic figure "peculiar to any emphatic speech": the heart speaks, the river plays; b) personification as a metaphor "its role is close to psychological parallelism that may be found in folk poetry and individual author's lyrics"; c) personification as a symbol directly connected with the central artistic idea" [14, p. 259]. The "Literary Encyclopedia" by L. Timofeev defines personification as an expression helping to understand an idea of any concept or phenomenon by presenting it in the form of a living being that has the properties of this concept (for instance, the Greek and Roman presented happiness in the form of a whimsical goddess of fortune). Often, personification is used to depict nature having certain human traits, "liveliness" [17, p. 272]. Personification is considered to be a manifestation of the anthropocentric principality [18, p. 13], reflected in poetry.

Some researchers tend to use the term "personified metaphor" or "metaphor-personification". According to E. Cherkasova, the metaphor becomes figurative as a result of inanimate objects becoming similar to the feelings and conditions of a human being and the living world taken as a whole [23, p. 218]. As long as personification is a transfer of signs of animateness to a concept or phenomenon, it may be called a type of metaphor. The object is already perceived as animate, as it is depicted.

Based on the semantic classification of metaphors, V. Kovalev defines personification as "the main type of metaphorization" and emphasizes the existence of a "broadly imaginable personification", having two varieties: "liveliness" of inanimate nature objects, zoomorphism and their "anthropomorphization", "a kind of artistic anthropomorphism" [5, p. 102].

3. Typology of personification in A. Fet's poetry. Anthropomorphism is a type of personification when the traits of a human being are attributed to inanimate and animate nature objects. Humanization is the most numerical group of personifications in A. Fet's poetry. For instance, in A. Fet's poem "One more night in May..." signs of anthropomorphism may be found:

What a night! Each and every Какая ночь! Все звезды до star единой

Looking into the soul warmly Тепло и кротко в дуиу смотand gently again... рят вновь...

Birches are waiting, etc. Березы жудт и т.д.

(A. Fet "One more night in (А. Фет «Еще майская Мау..."). ночь...»).

Zoomorphism is a type of personification when the traits of animals are attributed to objects and phenomena of animate and inanimate nature:

The space of your roots is Ползеm простор твоих snaking...

(A. Fet "Lonely oak"). (А. Фет «Одинокий дуб»).

Ornithomorphism is a type of personification when the traits of birds are attributed to objects or phenomena of animate and inanimate nature. For instance, in A. Fet's poem "Spring", this type of personification may be found in the following lines:

...Once again, the fragrant spring

Waved with a wing.

(A. Fet "Spring...").

...Опять весна душиста

Повеяла крылом.

(А. Фет «Весна»).

Phytomorphism is a type of personification when the traits of plants are attributed to objects or phenomena of animate and inanimate nature:

Lanits will come inti bloom - and Ланиты расцветуm - $u$ в thievishly in the mirror... зеркало украдкой...

(A. Fet “Don't say, my friend She (А. Фет «Не говори, мой друг will forget me...”). "Она меня забудет...”»).

Ethnomorphism is a type of personification when the traits of insects are attributed to objects or phenomena of animate and inanimate nature:

The buzz of spinning wheel of lazy Едва жужжит судьбы fate can barely be heard... ленивой прялка...

(A. Fet "There are strange moments: (А. Фет «Есть странные existence..."). минуты: бытие...»).

Achthyomorphism is a type of personification when the traits of fish are attributed to objects or phenomena of animate and inanimate nature:

The reflecting moon is floating Месяц зеркальный плывет по on the azure desert... лазурной пустыне..

(A. Fet "The reflecting moon is (А.Фет «Месяцзеркальный плыfloating on the azure desert...”). ветполазурнойпустыне...»).

The last two types of personification are quite rarely used in poetry.

E. Nekrasova defines personification as the "independent", "conscious" functioning of any object (in the enlarged sense of the word...)" [10, p. 120]. Characterizing the personification as an independent unit of the system of poetic language, the researcher reviews the current topics of the interaction between personification and other tropes in the structure of a literary text [10, p. 120].

J. Lakoff states that personification is a type of ontological metaphor attributing characteristics, features, and aspects of the activity of living beings to specific and abstract objects [1, p. 34]. Personification is mostly used for the description 
of nature, as well as mood or feelings of characters.

Personification is one of the key features of the author's creative thinking. The poet presents the details of the personified image on purpose, endows it with the traits of a human being. For instance, A. Fet's poem "To flowers" depicts a kind of conversation with flowers. The author presents plants as participants of a dialogue:

Children of the sunrise, Дети солнечного всхода, Flowers of varicolored pastures, Пестрых пажитей иветы, Nature has cherished уои B Вас взлелеяла природа In tribute to love and beauty. $\quad$ В честь любви и красотьь. Your bright dressing Ваши яркие уборы

Under the transparent finger of Под перстом прозрачным Flora

Is so elegantly beautiful; $\quad$ Так нарядно хорочи: But, favorites of spring prosperi- Но, любимиы неги вешней, ty,

Cry: the charm of external life

Did not put spirit into you.

(A. Fet "To flowers").

Плачьте: прелесть жизни внешней

Не вдохнула в вас души.

(А. Фет «К цветам»).

Using personification, A. Fet substantively illustrates such abstract concepts as "fate", "freedom", and "love". He describes them as living beings having a specific character, gives them a flavor of life.

Drilling down the linguistic specificities of personification, the researchers emphasize the following key features: the diversity of linguistic means of expression of personification in a text, the connection with both the paradigmatic and syntagmatic aspect of language.

In order to define personification, V. Moskvin introduces the term prosopopoeia (Medieval Greek prosopon "face" and poieo "I do, I create") [8, p. 22]. Otherwise stated, prosopopoeia "animates what is inanimate" [6, p. 145].

Figurativeness is a key function of personification in a literary text, it is focused on the formation of artistic quality. The researchers believe that the ethical function of personification is the ability of a human to perceive the world in terms of anthropomorphism [19, p. 33]. Personification is a valuable behavioral driver as long as it stimulates the development of such personality traits as goodwill and humanism [19, p. 33].

Personification also has an explanatory function. Lexemes for such human actions as to cry, to love, to wait are used to emphasize the results accompanying the natural events and the features that an event has as a result of the attitude of a human being towards it.

The mnemonic function of personification helps remember information better. "It seems that the emotional and evaluative nature of the image makes it easier to memorize it" [22, p. 43]. Hoverer, in the process of personification, both the intellectual and the emotional side of the personality are improved similarly. Personification helps a person to both understand and feel the life of the world around [21, p. 176].

As noted by V. Moskvin, the peculiar feature of personification lies in the fact that human qualities are attributed to objects, plants, animals and natural events - for instance, such as the power of speech, the ability to think, feel, act, etc. [8, p. 22]. Thus, personification provides an abstract concept with the features of a specific object.

Additionally, personification has a function of influencing the reader's imagination, as well as a function of forming a bright figurative world model. In A. Fet's poems, the markers of personification are verbs denoting human actions.

B. Bolkvadze distinguishes simple and complex personifications in terms of structure structure. "Simple personifica- tion are the tropes in which the process of personification is run using one catalyzer within a sentence (simple or compound). Personifications that occur in two or more independent phrases using two or more catalyzers are called complex ones" [3, p. 6].

Personification consists of a personified concept and a catalyzing word making act of personification possible.

B. Bolkvadze emphasizes: "The personified concept is expressed by a noun, the catalyzer is expressed by an adjective combined with a verbal copula, an adverb, a noun, a verb or a verb phrase (modal verb + infinitive), as well as a similar form of the verb (future tense form), a transgressive" $[3$, p. 4].

Personification, as a creative way of reflecting reality in verbal texts, is closely associated with anthropomorphism, the all times desire of people to attribute traits of a human being to objects and events of inanimate nature and to endow living beings and inanimate objects with features of a human being.

The subject of personification means what is being personified, and the object of personification means what the personified object follows. Here we are talking about both the objective world and lexical-semantic groups of nouns and predicates. For instance: The wind groans / Bemep воem: this verb describes a strong roaring of wind that acts as the subject of personification.

Lexical-semantic groups of personified objects are formed taking into consideration the degree of animateness of the object growing from inanimate nature to a human being. Personification is the attribution of the features and qualities of an object that has a higher degree of animateness to an object that has a lesser degree of animateness. Personification may be formed into two classes. The first class is made up of specific objects or phenomena (the forest has woken up / лес проснулся). The second class is made up of abstract concepts (the darkness has snuck up / темнота подкралась). Thus, inanimate objects and abstract concepts, becoming similar to animate objects, are the object of personification, and specific concepts become the subjects of personification.

The issue that characterizes the peculiarities of the functioning of personification as a mean of artistic description, which means that a particular object or phenomenon in various directions becomes similar to a human being, has two aspects in the individual author's style. First one designates its functional role, the second ones defines the ways of its linguistic implementation. A. Narushevich emphasizes that the artistic mean of personification in the linguistic aspect is associated with "the interaction of the meaning of animateness-inanimateness of the substantive and its semantic environment" $[9$, p. 135].

The authors of the monograph "The Digest of the History of the Language of Russian Poetry of the 20th Century: Tropes in an Individual Style and Poetic Language" [12, p. 33], identifying models of personification, the most universal way of creating personification is considered to be "the technique of 'turning over' real connections between a man and the world around", emphasizing such types as "switching connections and relationships between a man and nature" [12, p. 48], "switching connections and positions of the elements of the fixed situation" [12, p. 50] and "appealing to an inanimate object" [12, p. 53].

There can be distinguished several types of expression of personification depending on the means of expression of the personifying feature and its function in A. Fet's poetry. 
Personifying information is contained in both the predicate (coolness breathes / прохлада дылит) and the agreed definition (joyful green / веселая зелень). It makes sense to call the latter type of personification personificationsattributes where an anthropomorphic feature is contained in the agreed definition expressed by an adjective or participle. The agreed definition, forming personification, is considered to be a personifying epithet:

Finally: I will look out the win- Bom хоть теперь: посмотрю dow at the joyful green... за окно на веселую зелень...

(A. Fet "A kind of strange feel- (А. Фет «Странное чувство ing took possession of me in a какое-то в несколько дней few days...").

овладело...»)

The lake has fallen asleep; the Уснуло озеро; безмолвен лес...

forest is silent... (А. Фет «Уснуло озеро, без-

(A. Fet "The lake has fallen молвен лес...»).

asleep, the forest is silent...").

You have guessed the boredom Устальх прихотей ты разгаof tired whims... дала скуку..

(A. Fet "I am silently holding (А. Фет «Тебе в молчании я out my hand to you...”). простираю руку...»).

I will not call the forgetful youth Не стану кликать вновь заagain бывчивуюмладость

And its fellow traveler, vehe- И спутницу ее, безумную люment love...

бовь...

(A. Fet "Oh no, I will not call the (А. Фет О нет, не стану звать lost joy..."). утраченную радость...»).

The grass has faded, the desert Трава поблекла, пустыня is gloomy,

And the dream is abandoned in И сон сиротлив одинокой a lonely tomb... гробницьл...

(A. Fet "In the silence and dark- (А. Фет «В тиши и мраке таинness of a mysterious night...”). ственной ночи...»).

Motionless, dumb

Неподвижная, немая

The night is as bright as day... Ночь светла, как день...

(A. Fet "The warm wind can be (А. Фет «Тёплым ветром потяfelt..."). нуло...»).

The wind, the hollow-hearted Ветер, ветер лукавый, поди wind, get out of here... mbl...

(A. Fet "The nightingale and the (А. Фет «Соловей и роза»).

rose").

In the wilderness of the grass- $B$ степной глуши, над влагой land, above the silent moisture, молчаливой,

Where the round leaves are Где круглье раскинулись лиthrown around... стынl...

(A. Fet "In the wilderness of the (А. Фет «В степной глуши, над grassland, above the silent mois- влагой молчаливой...»). ture...”).

One more forgetful word... $\quad$ Еще одно забывчивое слово...

(A. Fet "One more forgetful (А. Фет «Еще одно забывчивое word...").

слово...»).

You, a soulless Rome, fell victim $T_{b l}$ caм, бездушный Pим, пал to wild power, жертвой силь дикой,

Like an old predatory beast... Как устаревший хишный (A. Fet "On the ruins of Caesar's зверь...

palace...").

(А. Фет «На развалинах цезарских палат...»).

We cannot be counted. Do not Нам нет числа. Напрасно overthink мыслью жсадной

to catch the shadow of the eter- Tbl думы вечной догоняешь nal thought..

(A. Fet "Among the stars"). тень...

He arbitrarily awakened dumb Немой восторг будил он самоadmiration,

But he failed to overcome the Но сумрака кругом не одолел... shadows all around... (A. Фет «Томительно-

(A. Fet "Deadly, inviting and призывно и напрасно...»). purposeless...").

I'm running. Snowdrifts. The Бегу. Сугробы. Мертвый лес dead forest sticks out... торчит... (А. Фет «Никогда»).
(A. Fet "Never").

How sorrowful are the sulky Как грустны сумрачные дни... days...

(A. Fet "Autumn").

...The shady garden was ...Стоял угрюм тенистый gloomy... cad...

(A. Fet "The was blowing. The (А. Фет «Дул север. Плакала grass was crying..."). трава...»).

A combination of techniques when the personifying information is simultaneously contained in both the predicate and the definition may be found:

...And let me wake up far away И пусть очнусь вдали, где к where to a nameless river речке безыменной

Runs a dumb grassland from the От голубых холмов бежит blue hills... немая степь...

(A. Fet "Oh no, I will not call the (А. Фет «О нет, не стану звать lost joy...").

Shy sadness stays silent... Молчит стылдивая печаль... (A. Fet “Autumn”). (А. Фет «Осень»).

So, A. Fet's poetry realizes the principle of separation from a human being, the transfer of reflection to the outside world of internal human qualities, states and traits to the objects of nature.

In attributive personifying syntagms are often used anthropomorphic participles in the role of the agreed definition and verbal nouns in genius constructions:

How the all-seeing May canпot Как не ивести всевидящему bloom мaю

With the glint of your darling При отблеске родном твоих eyes!.. очеü!...

(A. Fet "You don't suffer any (А. Фет «Ты отстрадала, я more, I am still suffering...”). еще страдаю...»).

...I love her murmuring arches of ...Люблю ее лесов лепечущие forests... (A. Fet "I am silently своды...

holding out my hand to you...”). (А. Фет «Тебе в молчании я простираю руку...»).

...A loose toy of a wistful dream. ...Игрушка шаткая тоску(A. Fet "To death").

ющей мечты. (А. Фет
«Смерти»).

...You are in front of my restless ...Tы пред моим мятущимся mind... сознаньем.

(A. Fet "The Powerful Lord should (А. Фет «Не тем, Госпоь, be incomprehensible for other kind могуч, непостижим...»). of people...").

Second group of agreed definitions containing a personifying feature is made up of definitions expressed by a noun:

My friend, rose, maiden-rose, Друг мой, роза, дева-роза, I wouldn't sing, if it weren't for Яб не пел, когда б не ты... уои... (А. Фет «Соловей и роза»).

(A. Fet "The nightingale and the rose").

A. Fedorov calls such definitions "expressed by an apposition" [20, p. 40]. Other researchers call the type of personification that attributes the features of plants to objects of animate and inanimate nature, phytomorphism:

Midnight is my birth mother, Полночь-мать моя родная,

I invisibly bloomed

At the dawn of spring...

Незаметно расцвела я rose").

In A. Fet's poetry, personifications also form genetic combinations, when, for instance, the actions of a human being are attributed to the time of day:

Oh, I will stay for a long time in the $O$, долго буду я, в молчаньи silence of the mysterious night... ночи тайной...

(A. Fet "Oh, I will stay for a long (А. Фет «О, долго буду я в time in the silence of the mysterious молчаньи ночи тайной...»). night...”). 
Attributing natural events to abstract states:

Back then when I was learning $B$ mе дни, как постигал $я$ my first love первую любовь

Through the rebellion of bluster- По бунту чувств неугомонing feelings... (A. Fet "When my rbix...

dreams are beyond the past (А. Фет «Когда мои мечты за days..."). гранью прошлых дней...»)

The image of a part of the human body is attributed to the objects of animate nature:

A bold face of freedom and а Свободы смельй лик и томsoulful look of love... ный взор любви...

(A. Fet "I know, proud-hearted (А. Фет «Я знаю, гордая, ты you, you love absolute power...”). любишь самовластье...»).

I love the conversation of silent Люблю безмолвных ycm $u$ lips and eyes... взоров разговор...

I love the silence of the midnight Люблю безмолвие полунощnature... ной природы...

(A. Fet "I am silently holding out (А. Фет «Тебе в молчании я my hand to you..."). простираю руку...»).

I am ready to sit all night, all Всю ночь, всю эту ночь я night long, $\quad$ просидеть готов,

Looking in the face of the dawn Смотря в лицо зари иль вдоль or along the gray road... дороги серой...

(A. Fet "I will go towards them on (А. Фет «Пойду навстречу к the known path..."). ним знакомою тропою...»).

From the face of the earth, where С лица земли, где все темно everything is dark and poor, $\quad$ и скудно,

To us, into our depths, where К нам, в нашу глубь, где пышeverything is splendid and light... но и светло...

(A. Fet "Among the stars"). (А. Фет «Среди звезд»).

...I used to forgot hunger and ...И голод забывал и жажду many days of thirst, многих дней,

Listening to the voice of the Внимая голосу пустыни...

desert... (А. Фет «Когда Божествен-

(A. Fet "When the Divine escaped ный бежал людских pehuman speeches..."). чей...»).

...Him, desirous, on the crown of ...Его, взалакшего, на темя gray crag... серых скал...

(A. Fet "When the Divine escaped (А. Фет «Когда Божественhuman speeches..."). ный бежал людских речей...»).

.A trace of the dawn of autumn is ...Зари осенней след в мерияin this shimmer.. ньи этом есть...

(A. Fet "Sprawled in an armchair I (А. Фет «На кресле отвалясь, am look at the ceiling...”). гляжу на потолок...»).

.And as in a tiny dewdrop И как в росинке чуть замет-

Үои recognize the face of the ной

sun...

(A. Fet "Good and evil").

Весь солнца лик ты узнаemb...

..and dahlias

(А. Фет «Добро и зло»). ...и георгины

Are burned with the breath of the Дыханьем ночи обожгло... night...

(A. Fet "Autumn rose").

(А. Фет «Осенняя роза»).

Personification, as a phenomenon of style, determines the poet's attitude towards nature.

The most common place for the concentration of personification is two-member sentences with a simple verb predicate:

A strange feeling took possession Странное чувство какое-то in a few days... в несколько дней овладело...

(A. Fet "A strange feeling took (А. Фет «Странное чувство possession in a few days..."). какое-то в несколько дней овладело...»).

The lake has fallen asleep... Уснуло озеро...

(A. Fet "The lake has fallen (А. Фет «Уснуло озеро; безasleep; the forest is silent...”). молвен лес...»).

Yои are oppressed by soтеоле Тебя в ревнивом сне томит else's happiness in a jealous чужое счастье...

dream...

Лобзает ветр один руно его
A fleece of his curls is kissed by кудрей...

$\begin{array}{ll}\text { the wind... } & \text { (А. Фет «Я знаю, гордая, ты }\end{array}$

(A. Fet "I know, proud-hearted любишь самовластье...»).

you, you love absolute power...").

...The young breast will sigh of ...Вздохнет младая грудь

slow speeches... замедленных речей...

Unknowingly the glance will start Невольно станет взор с

running with a question... вопросом забегать...

(A. Fet "Don't say, my friend: (А. Фет «Не говори, мой друг:

'She will forget me..."). "Она меня забудет..."»).

The windows are with bars, and Окна в решетках, и сумрачны the faces are sorrowful, лица,

Anger is hatefully looking at the Злоба гдядит ненавистно на brother; брата;

I am familiar with your walls, Я признаю твои стены, темdungeon, нииа, -

A banquet of youth celebrated Юности пир ликовал здесь here once... когда-то...

(A. Fet "The windows are with (А. Фет «Окна в решетках, и bars, and the faces are sorrow- сумрачны лица...»).

ful...").

And it seems I understand, $\quad$ И мне -мне кажется понят-

What the leaves are whispering to $\mathrm{нo}$,

the dome...

. Смиренно празднует душа.

(A. Fet "Not the first year at these (А. Фет «Не первый год у places..."). этих мест...»).

As a lily looks into a mountain Как лилея глядится в нагорstream...

(A. Fet "Alter ego"). ный ручей...

We are burning here, so that in $\mathrm{Mbl}$ здесь горим, чтоб в суthe impenetrable shadows мрак непроглядный

$A$ infinite day will go towards $K$ тебе просился беззакатyou...

(A. Fet “Among the stars"). (А. Фет «Среди звезд»).

...In its smoke, as in creative ...B его dblмy, как в творчеdreams ских грезах

The entire power trembles and all Вся сила дрожит и вся вечeternity is appearing in dreams... ность снится...

(A. Fet "Jaded by life, by the (А. Фет «Измучен жизнью, treachery of hope..."). коварством надежды...»).

What are you doing? What for? - Что ж ть? Зачем? - Мол-

Feelings and mind are both чат ичувства и познанье...

silent...

(А. Фет «Ничтожество»).

(A. Fet "Insignificance").

When my dreams are beyond the Когда мечты мои за гранью past days прошилых дней

Will find you again behind the Найдуm тебя опять за дыммhaze fog... кою туманной..

(A. Fet "When my dreams are (А. Фет «Когда мечты мои за beyond the past days...”). гранью прошлых дней...»).

The warmth of love will inhale - Дохнет тепло любви, the baby's еуе... м младенческое око...

(A. Fet "The world does not know (А. Фет «Ее не знает свет, her, she is still a child...”). она еще ребенок...»).

The stars are sending their imag- Шлют звезды в инее свое es in hoarfrost... изображенье...

Under the fast foot a frozen Под быстрою стопой проground мерзлая земля

Sounds also on a steep, although Звучum $и$ no крутой, хотя recent freezing weather... недавней стуже...

(A. Fet "Hey, joke-youth! Like (А. Фет «Эй, шуткаnew early snow...”). молодость! Как новый ранний снег...»).

Life said the last sentence for us... Сказала жизнь за нас по(A. Fet "I am silently holding out следний приговор... my hand to you...").

(А. Фет «Тебе в молчании я простираю руку...»).

Why is your ghost laughing sо Что ж так язвительно смеsarcastically ется призрак твой

And looking at me with heavily?.. И смотрит на меня таким 
(A. Fet "I cannot sleep. Let me тяжельим взором?.

light a candle. Why read?.."). (А. Фет «Не спится. Дай зажгу свечу. К чему читать?..»).

Wait! I like to be here! Jagged Постой! здесь хорошо! Зубand wide чатой и широкой

Stripe shadow fell from the pine Каймою тень легла от сосен trees in the moonlight... в лунный свет...

(A. Fet "Wait! I like to be here! (А. Фет «Постой! здесь хороJagged and wide...”). шо! Зубчатой и широкой...»).

Wait! Insane anxiety Постой! Безумная тревога

Will fall asleep in a jaded chest... Уснет в измученной груди... (A. Fet "To death"). (А. Фет «Смерти»).

Nesting, from a hillock forget-me- Гнездясь, с пригорка незабудnots $\kappa и$

Are looking bravely into the Глядят смелее в даль стеdistance of the grasslands... nей...

(A. Fet “Lonely oak"). (А. Фет «Одинокий дуб»).

My ashes will fall asleep forgotten Мой прах уснет забытый и and cold...

(A. Fet "Now").

холодный...

Autumn is looking for burning Горящих осень ищет взоeyes...

(A. Fet "Autumn").

ров...

A warm wind blows quietly, Тепльій ветер тихо веет,

The grassland breathes with fresh Жизнью свежей дышит life...

cmenb...

(A. Fet "A warm wind blows (А. Фет «Теплый ветер тихо quietly"). Bеeт»).

The ruin is silent in the pride of В тумане утреннем развалиthe morning... на.молчит...

(A. Fet "On the ruins of Caesar's (А. Фет «На развалинах цеpalace..."). зарских палат...»).

In my chest a living heart beats В груди моей сильней живое stronger, сердие бьется,

And blood runs faster in mу И в жилах кровь бежит veins... быстрей...

(A. Fet "On the ruins of Caesar's (А. Фет «На развалинах цеpalace"). зарских палат»).

The coolness of the evening both Прохлада вечера и дышит, $u$ breathes and does not breathe... не дышит..

(A. Fet "I will go towards them on (А. Фет «Пойду навстречу к the known path..."). ним знакомою тропою...»).

The north was blowing. The grass Дул север. Плакала трава... was crying...

(A. Fet "The north was blowing. трава...»).

The grass was crying...").

...The night cries with dews of ...Росою счастья плачет happiness.

(A. Fet "Don't blame me for (A. Фет «Не упрекай, что я being shy...").

...And being silent we hear

That we wing with our stream,

A fountain sings to us...

(A. Fet "Fountain").

смущаюсь...»).

...И, безмолвные, мы сльишим, Что, струей своей кольшии, Напевает нам фонтан... (А. Фет «Фонтан»).

...The dawn will tell that the day ...Поведает заря, что минул of foul weather has passed... день ненастья...

(A. Fet "Forgive and forget (А. Фет «Прости - и все заeverything in a cloudless hour...”). будь в безоблачный ты час...»).

Although the memory states that Хоть памяmь $u$ твердиm, there is a grave between us... что между нас могила...

(A. Fet 'No, I haven't changed. (А. Фет «Нет, я не изменил. Until great age...”). До старости глубокой...»).

Only a fountain is murmuring in Лепечет лишь фонтан средь the midst of the distant darkness... дальней темноты...

(A. Fet "Everything around is (А. Фет «Устало все кругом: tired: the color of heaven is tired устал и цвет небес...»).

as well...").

Below, the faded garden fell Внизу померкший сад уснул,asleep - only a distant poplar... лишь тополь дальный...
(A. Fet “Oh, I feel anxiety...”). (А. Фет «O, как волнуюся я мыслию больною...»).

And the leaves and stars are $И$ листья $и$ звезды mpenetrembling... uym...

You are so innocent that mundane Tbl так чиста, что помыслы desires земные

Are involuntarily die in the chest Невольно мрут в груди перед in front of you... тобой...

The echo is waiting to begin to Эxо ж⿻上丨 завторить nerepeat... Hью..

The forest space is waiting... Жоет лесной простор...

If the echo will stay silent about Если эхо о них промолчит...

them...

(A. Fet "The nightingale and the

rose").

Only you have short-lived day- Только у вас мимолетные dreams грезы

Looking into the soul as old Cтарыми в душу глядятся friends... друзьями ...

(A. Fet "Poets"). $\quad$ (А. Фет «Поэтам»).

There, finally, I was everything ту Там наконеи я все, чего душа soul strived for,

Waited, hoped, in later life I will Ждала, надеялась, на склоне find... лет найду..

(A. Fet "Oh no, I will not call the (А. Фет «О нет, не стану звать lost joy...”). у утраченную радость...»).

...where there is a huge shaft in ...где в море вал огромный

the sea Придет - и убежсит в объя-

It will come and run away into the тия валов....

arms of the shafts.... A там придет волна - $u$

And there will come a wave and it грянет между нами...

$\begin{array}{ll}\text { will crush between us... } & \text { (А. Фет «Постой! здесь хоро- }\end{array}$

(A. Fet "Wait! I like to be here! шо! зубчатой и широкой...»).

Jagged and wide...").

In the last poem we can see the personification formed by the genetic combination, which was mentioned above: the arms of the shafts / объятия валов.

These personifications use verbs, which, by their meaning, express action, state, movement, processes and events covering the subject. These personifications have some traits, qualities and internal states of a human being.

The semantics of nominal properties can be varied, but most often they convey the emotional or existential states of the personified object:

The pond is like shiny steel, Пруд как блестямая сталь,

Herbs in sobbing... Tравы в рыдании...

(A. Fet "In the moonlight"). (А. Фет «В лунном сиянии»).

Additionally, the objects of the outside world, which also interact with the lyrical hero, are personified:

Where a wild apple and a plum Где с дикой яблонью убором are comparing their dresses, спорит слива,

Where a cloud is barely snaking, Где тучка чуть ползет, airy and light, воздушна и светла,

Where a jaded willow is drowsing Где дремлет над водой поabove the water... никнувшая ива...

(A. Fet "Oh no, I will not call the (А. Фет «О нет, не стану звать lost joy...”). утраченную радость...»).

A. Fet used personifications, which are created through an appeal to an inanimate object or natural event, representing it as a participant of a dialogue:

Hello! A thousand times my hello Здравствуй! Тысячу раз мой to you, night! привет тебе, ночь!

(A. Fet "Hello! A thousand times (А. Фет «Здравствуй! тысячу hello to you, night!"). аз мой привет тебе, ночь!»).

And I love, faded beauty, $\quad$ Ия люблю, увядмая краса,

Your lingering look, so cold and Твой долгий взор, надменный dull...

(A. Fet "Italy"). (А. Фет «Италия»).

Oh first lily of the valley! From O первый ландыш! Из-под under the snow снега 
You need the sun rays...

Тыпросишь солнечныхлучей.. (A.Fet “The first lily of the valley"). (А. Фет «Первый ландыш»).

There are also "personifications of the psychological type" $[9$, p. 90], the features of which are most clearly manifested in the dialogue of the lyrical hero with the personified object:

But, Rome, I am glad that sad and Ho, Рим, я радуюсь, что vain

You are here at my feet! грустный и ничтожный Ты здесь у ног моих приник! palace...").

цезарских палат...»).

Sometimes the poet uncovers the technique, detailing the personifications.

Together with the traditional means of expression of personification, A. Fet also uses less common ones. Thus, sometimes in his poetry may be noted such techniques when personification is based on the transition of a noun into a proper name when describing a particular state or when referring to one or another object of nature:

$\begin{array}{ll}\text { I do not want a frosty } & \text { Не хочу морозной я } \\ \text { Eternity, } & \text { Вечности, } \\ \text { But I want a tearless } & \text { Ахочу бесслезной я } \\ \text { Youth, } & \text { Младости, } \\ \text { With burning desire, } & \text { Согненным желанием, } \\ \text { Full of } & \text { Полной упованием } \\ \text { Joy. } & \text { Радости. }\end{array}$

(A.Fet “I don't want frosty...”) (А.Фет«Не хочу морозной я...»)

These examples are used in a generalized symbolic meaning, form contextual names:

But the enlightened daughter of Но просветлённая дочь лучеthe splendid Phoebus, with the зарного Феба, дыханьем breath Ночи безмолвной полна, невозOf silent night, the imperturbable мутимая Смерть,

Death is full, $\quad$ Увенчавши своё чело непо-

Crowning her forehead with a движной звездою,

motionless star, Не узнаёт ни отия, ни без-

Does not recognize neither her fa- утешную мать.

thernorherinconsolablemother. (А. Фет «Сон и смерть»).

(A. Fet "Sleep and Death").

And all are equal before the И равны все звенья пред ВечEternal Holм

In the continuous chain of crea- В иепи непрерывной творенья, tion,

And with the total trepidation

И жизненнымм

трепетом

Wonderful links are made... общимм

Исполнены чудные звенья...»

(A. Fet "The nightingale and the (А. Фет «Соловей и роза»). rose").

Also, the personification may be based on the transformation of a toponym into an anthroponym in the figure of appeal:

Italy, you lied to the heart! Италия, ты сердиу солгала!

How long I cherished you in ту Как долго я в душе тебя soul, лелеял,-

But you was different from the Но не такой мечта тебя dream, нашла,

And your breath seemed lien to Ине родным мне воздух твой me... повеял...
(A. Fet "Italy").
(А. Фет «Италия»).

Another means of expression of personification is the appeal as an appeal to the addressee. There are cases when entire text of the poem is constructed in the form of an appeal to the personified object. The brightest technique of this kind is attribution of feelings of a human being (feelings of love) to the outside world: when appealing to the addressee there usually used one of the most common forms of appeal, in particular the form you, Yои. In this poem, personification has a text-forming function, and the feeling of love is personified. The appeal is supported by the pronoun of the second person in singular form:

And I love, faded beauty,

Ия люблю, увядшая краса,

Your lingering look, so cold and Твой долгий взор, надменный и dull... (A. Fet "Italy").

уныльии... (А. Фет «Италия»). form:

The appeal may be formed using the second person in plural

How long will I drink your blinking Долго ль впивать мне мериаSearching eyes of the blue sky? ние ваmе,

How long does it take to feel that Синего неба пытливые очи?

there is nothing higher and better Долго ли чуять, что выше и than you краме

In the temple of the night? Вас ничего нет во храмине Maybe you are not under those ночи? lights:

Может быть, нет вас под

The old era blew you out, - теми огнями:

So after death I will fly to уои in Давняя вас погасила эпоха,poetry, Так и по смерти лететь $к$

To the ghosts of the stars, I will be вам стихами,

the ghost of a sigh! $K$ призракам звезд, буду

(A. Fet "To Fading stars"). призраком вздоха!

(А. Фет «Угасшим звездам»).

The semantics of the second person shortens the distance between a man and the subject of speech.

The key factor of depicting personification in A. Fet's poetry is usually the adverbs expressing feelings and emotions peculiar only to people and animals:

Above mountains of rubbish, Над грудой мусора, где where the ivy sadly climbs... п плюш тоскливо вьется...

(A. Fet "On the ruins of Caesar's (А. Фет «На развалинах palace"). цезарских палат»).

The personification is also implemented with the help of comparisons used by A. Fet, in which objects of nature or stars are identified and compared with living objects - people, animals, birds:

Like a young swan, the mоon Как лебедь молодой, луна among the heavens среди небес

Slides and looks at its twin on Скользит и свой двойник на moisture... влаге созериает...

(A. Fet "The lake has fallen (А. Фет «Уснуло озеро, безasleep, the forest is silent...”). молвен лес...»).

Depicting personification, A. Fet uses a personifying detail, attributing features of the appearance of a human being to the seasons:...

A gratifying smile of the spring, - ...Еще весны отрадная ульбBut the linden did not blossom...; $\quad \boldsymbol{\kappa} \boldsymbol{a},-$

Displeasure and shame are Но в этот раз не распустиburning the cheeks... лась липка...,

(A. Fet "Oh, I will stay in the Досады $и$ стыда румянами silence of the secret night for a палимы...

long time...").

(А. Фет «О, долго буду я в молчаньи ночи тайной...»).

The lovely pages are opened the Страницы милье опять fingers again...

персты раскрыли...

(A. Fet "The lovely pages are (А. Фет «Страницы милые opened the fingers again...”). опять персты раскрыли...»).

The garden bared its forehead... Сад обнажил свое чело...

(A. Fet "Autumn Rose"). (А. Фет «Осенняя роза»).

Conclusion. It follows that the key type of personifications and personifying signs is represented by a combination of inanimate nouns with third-person verbs denoting traits of a human being.

Thus, personification, as one of the most crucial means of figurativeness, being used for the description of natural events and artifacts in the world around, is a multifunctional phenomenon. It is used in a work depending on the specific author's tasks and the purpose to be achieved. One of the functions of personification is the pictorial function. Among other things, personification has general stylistic functions in 
a poetic work: expressive, meaning the direction of the linguistic sign to increase the expressiveness of the words, the growth of movement in the text. The most common means of creation of personification used by A. Fet is the use of verbal metaphors. Thanks to personifications it is possible to create a specific and symbolic perspective of the image, which is based on individual ideas about the world, man, and nature combining with new poetic associations close to the addressee. The results of the analysis make it possible to conclude that the stylistic technique of personification is highly potential thanks to its diversity, and is the key means of implementation of the author's intentions in a poetic text.

\section{REFERENCES}

1. Lakoff G., Johnson M. Metaphors We Live By. Chicago and London: The University of Chicago Press, 1980. 242 p.

2. Бельчиков Ю.А. Олицетворение // Русский язык: Энциклопедия / под. ред. Ф.П. Филин. М.: Советская энциклопедия, 1979. С. $176-177$.

3. Болквадзе Б.И. Олицетворение как феномен речевого художественного мышления (на материале русской и грузинской лирики 19 в.): Автореф. дис. ...канд.филол.наук. Воронеж: Воронежский гос.уни-т., 1995. 26 с.

4. Квятковский А.П. Поэтический словарь / А.П. Квятковский. М.: Советская энциклопедия, 1966. 376 с.

5. Ковалев В.П. Выразительные средства художественной речи / В.П. Ковалев. К.: Рад. шк., 1985. 136 с.

6. Лами Б. Риторика, или Искусство речи // Е.Л. Пастернак. «Риторика» Лами в истории французской филологии. М.: Языки славянской культуры, 2002. С. 59-313.

7. Літературознавчий словник-довідник / Р.Т. Гром'як, Ю.І. Ковалів та ін. К.: ВЦ «Академія», 1997. С. 656.

8. Москвин В.П. Выразительные средства современной русской речи. Тропы и фигуры. // Терминологический словарь. 3-е изд. Ростов-на-Дону: Феникс, 2007. 940 с.

9. Нарушевич А.Г. Категория одушевленностинеодушевленности в свете теории поля: дисс. ... канд. филол. наук / А.Г. Нарушевич. Таганрог Таганрогский пед. инт., $1996.163 \mathrm{c}$.

10. Некрасова Е.А. Олицетворение // Очерки истории языка русской поэзии XX века: Тропы в индивидуальном стиле и поэтическом языке. М.: Наука, 1994. С. 13-105.

11. Одинцов В.В. Стилистика текста / В.В. Одинцов. М.: Наследие, 2004. 379 с.

12. Очерки истории языка русской поэзии XX века: Тропы в индивидуальном стиле и поэтическом языке / В.П. Григорьев, Н.Н. Иванова, Е.А. Некрасова,

2. Belchikov Yu. Personification // Russian language: Encyclopedia / edited by F. Filin. Moscow: Sovetskaya entsiklopediya, 1979. P. 176-177.

3. Bolkvadze B. Personification as a phenomenon of verbal creative thinking (based on Russian and Georgian lyric poetry of the 19th century). Voronezh: Voronezhskiy Gosudarstvennyy universitet, 1995. $26 \mathrm{p}$.

4. Kvyatkovsky A. Poetic Dictionary. Moscow: Sovetskaya entsiklopediya, 1966. 376 p.

5. Kovalev V. Expressive means of artistic speech. Kyiv: Radyanska shkola, 1985. $136 \mathrm{p}$.

6. Lami B. Rhetoric, or the Art of Speech / edited by E. Pasternak. Lamy's "Rhetoric" in the History of French Philology Moscow: Yazyki slavyanskoy kultury, 2002. P. 59-313.

7. Literary vocabulary / edited by R. Gromyak, I. Kovaliv et al. Kyiv: Akademiya, 1997. P. 656.

8. Moskvin V. Expressive means of modern Russian speech. Tropes and figures. // Terminological dictionary. 3rd edition. Rostov-onDon: Feniks, 2007. 940 p.

9. Narushevich A. Category of animateness-inanimateness in the light of field theory. Taganrog: Taganrogskiy Pedagogicheskiy Institut, 1996. $163 \mathrm{p}$.

10. Nekrasova E. Personification//Essays on the history of the language of Russian poetry of the 20th century: Tropes in an individual style and poetic language. Moscow: Nauka, 1994.P.13-105.

11. Odintsov V. Stylistics of the text. Moscow: Naslediye, 2004. $379 \mathrm{p}$.

12. Essays on the history of the language of Russian poetry of the 20th century: Tropes in an individual style and poetic language / Grigoriev V., Ivanova N., Nekrasova E., Severskaya O. Moscow:
О.И. Северская. М.: Наука, 1994. С. 10.

13. Потебня А.А. Теоретическая поэтика / А.А. Потебня. М.: Высшая школа, 1990. 344 с.

14. Роднянская И.Б. Олицетворение / И.Б. Роднянская // Краткая литературная энциклопедия в 10 т. / под ред. А.А. Суркова. М.: Советская энциклопедия, 1968. Т. 5. C. $423-426$.

15. Розенталь Д.Э., Теленкова М.А. Словарь-справочник лингвистических терминов / Д.Э. Розенталь, М.А. Теленкова. 3-е изд., испр. и доп. М.: Просвещение, 1985. 399 с.

16. Стилистический энциклопедический словарь русского языка/под ред. М.Н.Кожиной. М.: Флинта: Наука, 2003. С. 559.

17. Тимофеев Л.И. Основы теории литературы / Л.И. Тимофеев. М.: Просвещение, 1976. С. 272.

18. Топоров В.Н. Тропы // Большой энциклопедический словарь: Языкознание. М.: Большая Российская энциклопедия, 1998. C. 521.

19. Ушинский К.Д. Собр. соч. / К.Д. Ушинский. М., Л.: Изд-во пед наук, 1950. Т.8. $773 \mathrm{c}$.

20. Федоров А.И. Семантическая основа образных средств языка / А.И. Федоров. Новосибирск: Наука, 1969.92 с.

21. Филатов В.П. Парадоксы эмпатии // Загадка человеческого понимания. М.: Политиздат, 1991. С. 176-196.

22. Харченко В.К. Функции метафоры / В.К. Харченко. Воронеж: Изд-во ВГУ, 1992. 88 с.

23. Черкасова Е.Т. Опыт лингвистической интерпретации тропов / Е.Т. Черкасова. М.: Наука, 1968. 396 с.

24. Шпет Г.Г. Внутренняя форма слова: Этюды и вариации на темы В. Гумбольдта / Г.Г. Шпет. М.: Изд-во Гос. академии худож. наук, $1927.219 \mathrm{c}$.

25. Ярцева В.Н. Лингвистический энциклопедический словарь / В.Н. Ярцева М.: Советская энциклопедия, 1990. 685 с.

\section{REFERENCES}

Nauka, 1994. P. 10.

13. Potebnya A. Theoretical poetics. Moscow: Vysshaya shkola, 1990. $344 \mathrm{p}$.

14. Rodnyanskaya I. Personification. V.5. // Brief literary encyclopedia in 10 volumes / edited by A. Surkov. Moscow: Sovetskaya entsiklopediya, 1968. P. 423-426.

15. Rosenthal D., Telenkova M. Dictionary of linguistic terms. Moscow: Prosveshcheniye, 1985. 399 p.

16. Stylistic encyclopedic dictionary of the Russian language / edited by M. Kozhina. Moscow: Flinta: Nauka, 2003. P. 559.

17. Timofeev L. Fundamentals of the theory of literature. Moscow: Prosveshcheniye, 1976. P. 272.

18. Toporov V. Tropes // Big encyclopedic dictionary: Linguistics. Moscow: Bolshaya Rossiyskaya Entsiklopediya, 1998. P. 521.

19. Ushinsky K. Collected works. V.8. Moscow, Leningrad: Izdatelstvo pedagogicheskih nauk, $1950.773 \mathrm{p}$.

20. Fedorov A. The semantic basis of the figurative means of the language. Novosibirsk: Nauka, 1969. 92 p.

21. Filatov V. The paradoxes of empathy // The puzzle of human understanding. Moscow: Politizdat, 1991. P. 176-196.

22. Kharchenko V. Functions of metaphor. Voronezh: Izdatelstvo Voronezhskogo Gosudarstvennogo Universiteta, 1992. 88 p.

23. Cherkasova E. Experience of linguistic interpretation of tropes. Moscow: Nauka, 1968. 396 p.

24. Shpet G. The inner form of the word: Studies and variations on the theme by V. Humboldt. Moscow: Izdatelstvo gosudarstvennoy akademii khudozhestvennykh nauk, 1927.219 p.

25. Yartseva V. Linguistic encyclopedic dictionary. Moscow: Sovetskaya entsiklopediya, 1990.685 p. 